\title{
Developing islamic context-based learning materials in increasing students' mathematical
}

\author{
Maria Ulpah ${ }^{1}$, Ifada Novikasari ${ }^{1}$ \\ ${ }^{1}$ IAIN Purwokerto, Indonesia \\ 凹ulfah1511@yahoo.co.id*
}

\section{Article Information}

Submitted November 04, 2019

Revised April 15, 2020

Accepted April 21, 2020

\section{Keywords}

Islamic education;

Learning Material;

Mathematics Understanding.

\begin{abstract}
Learning material is an important part of the implementation of learning, so teachers should be able to design, arrange, and develop their learning material. There are a lot of mathematics learning materials on the market but they are still rarely integrated with Islamic studies. Therefore, the purpose of this study is to develop Islamic context-based learning material to increase students' mathematical understanding. This study is research and development using the PPE model which consists of three stages, namely planning, production, and evaluation. The data collecting techniques used are tested to find out the students' mathematical understanding and questionnaire to find out expert's assessment. The data is analyzed quantitatively using descriptive data analysis techniques. The data obtained from the questionnaire is quantified to get results in the form of percentages to find out the results of the questionnaire from the validation of the learning material experts. The results showed that Islamic context-based learning material has fulfilled the requirements to be considered feasible to be used in the learning process and is feasible to be used as learning support to increase students' mathematical understanding.
\end{abstract}

\section{INTRODUCTION}

Learning material is an important part of the implementation of education, teachers will be easier to carry out learning and students will be more helped and easier to learn (Arsanti, 2018). Learning materials that are widely used are textbooks, so it must be able to present subject matters that are easily understood by students. Students who have a good experience background who support the subject matters do not have many problems before learning and in the subsequent learning process. But for students who lack experience related to the material will face problems in learning, especially related to their readiness to learn. This applies to all subjects including mathematics.

Many math learning materials are available in the market, both in the form of worksheets and textbooks. However, developing own teaching materials needed for learning and following the conditions of students is a professional responsibility for teachers and interested parties (Zulkifli \& Royes, 2018). This is because the world of education is dynamic as humans as the subject of learning with a variety of social, economic, cultural, religious, political contexts that always lie behind all the time. Teaching material in the form of textbooks, modules, worksheets, or the other for mathematics lessons at elementary, secondary, and tertiary levels is teaching material that contains learning material in the context of enhancing faith, piety, noble character, and personality, mastery of science and technology, enhancement of sensitivity and aesthetic abilities, enhancement of kinesthetic and health capabilities compiled based on national education standards, as stipulated in the regulation of the minister of national education number 11 of 2005 concerning textbooks.

$\begin{array}{ll}\text { How to cite } & \text { Ulpah, M. \& Novikasari, I. (2020). Developing islamic context-based learning materials in increasing students' } \\ & \text { mathematical. Al-Jabar: Jurnal Pendidikan Matematika, 11(1), 29-38. } \\ \text { E-ISSN } & 2540-7562 \\ \text { Published by } & \text { Mathematics Education Department, UIN Raden Intan Lampung. }\end{array}$


Based on that rule, learning materials developed must be able to improve abilities (Ulpah, 2017), such as understanding. The importance of students having good understanding was raised by Santrock (2012), that understanding concept is a key aspect of learning. Likewise, mathematical understanding is an important basis for thinking in solving mathematical problems and real-life problems. Also, the ability of mathematical understanding is very supportive in the development of other mathematical abilities, namely communication, problem-solving, reasoning, connection, representation, critical thinking, creative thinking, and mathematical thinking. This opinion is similar to that expressed by Wiharno that the ability to understand concepts is an ability that must be considered during the process of learning mathematics, especially to gain meaningful mathematical knowledge (Hendriana et al, 2017).

At the tertiary level, especially in the Mathematics Education Study Program, mathematics teaching materials need to be developed that are following the needs of students, as well as in the context of their daily lives. Students in Mathematics Education Study Program of IAIN Purwokerto are prospective teachers of SMP/MTs/SMA/MA. There are differences between the SMP/SMA curriculum and the MTs/MA curriculum. In the MTs/MA curriculum, many courses contain Islamic education, such as Fiqh, History of Islamic culture, Arabic, morality, etc., as well as mathematics education curriculum of IAIN Purwokerto, which has a lot of Islamic education. Therefore, the mathematics learning material used should be adapted to the daily context of students who have a lot of Islamic education (or referred to as the Islamic context).

Several studies have been carried out to develop mathematics learning materials to facilitate the learning process (Agustyarini \& Jailani, 2015; Budiman \& Ramdhani, 2017; Gazali, 2016; Hasibuan et al., 2018; Kharisma \& Asman, 2018; Maharani, 2017; Nurhasanah, 2017; Nurhidayati et al., 2017; Peranginangin et al., 2019; Putri, 2016; Safitri, 2017; Saputra et al., 2016; Somakim et al, 2016; Ulandari et al., 2019), and research to increase students' mathematical understanding (Alan, 2017; Eriana et al., 2019; Kariadinata et al., 2019; Lestari, 2018; Mahmudi et al., 2018; Mardiana et al., 2017; Minarni et al., 2016; Purwadi et al., 2019). However, no previous research has developed Islamic context-based learning materials to increase students' mathematical understanding.

Based on the research, the renewal in this study lies in the development of an Islamic context-based mathematics learning materials in relation, function, sequence and series material for students. So, the purpose of this study is to develop an Islamic context-based mathematics learning material in increasing students' mathematical understanding.

\section{METHODS}

The research method used in this study is research and development ( $R \& D$ ) which refers to the PPE model (Planning, Production, and Evaluation) (Sugiyono, 2019). Planning means the activity of making a product plan to be made for a specific purpose. Production means the activity of making products based on designs that have been made. Evaluation is the activity of testing and assessing how high the product meets the specified criteria. The model is presented in Figure 1. 

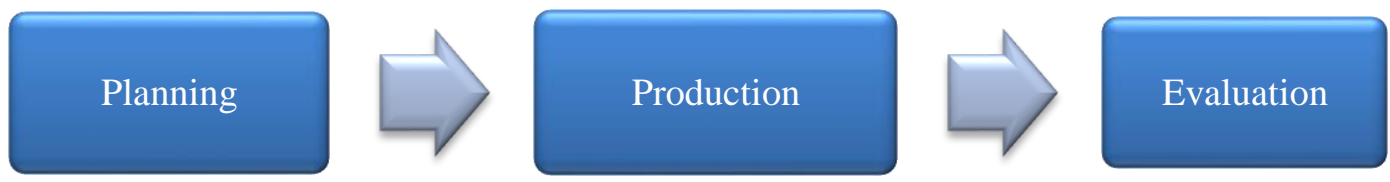

Figure 1. PPE Development Model

Figure 1 shows that the research consists of three stages. The first stage is planning which is determining mathematical topics to be discussed, conducting kinds of literature and making instruments. The next stage is production, which is making learning materials about topics that have been determined by paying attention to the style of language, images, fonts, and context. The last stage is evaluation, which is validating learning materials by experts and trying it out to students.

Data collecting techniques used are tests and questionnaires. Data is analyzed quantitatively using descriptive data analysis techniques. The data obtained from the questionnaire is quantified to get results in the form of percentages to find out the results of the questionnaire from the validation of the learning material experts (Wulandari, 2017).

Table 1. Advisability Criteria of Learning Material

\begin{tabular}{cl}
\hline Interval $(\boldsymbol{i})$ & \multicolumn{1}{c}{ Criteria } \\
\hline $85 \%<i \leq 100 \%$ & Feasible of a very good predicate \\
$65 \%<i \leq 85 \%$ & Feasible of a good predicate \\
$45 \%<i \leq 65 \%$ & Feasible of an enough predicate \\
$0 \%<i \leq 45 \%$ & Not feasible \\
\hline
\end{tabular}

Table 1 shows the percentage range value as a reference for evaluating the results of the experts' validation. To see an increase in students' understanding of learning before and after being given treatment, the researchers used $\mathrm{N}$-gain.

Table 2. N-Gain Value Criteria

\begin{tabular}{cl}
\hline Interval $(\boldsymbol{g})$ & \multicolumn{1}{c}{ Criteria } \\
\hline$g>0,7$ & High \\
$0,3 \leq g \leq 0,7$ & Moderate \\
$g<0,3$ & Low \\
\hline
\end{tabular}

Table 2 describes the N-Gain value criteria for students' mathematical understanding while using Islamic context-based learning materials in learning.

\section{RESULTS AND DISCUSSION}

This research was conducted using the Research and Development (R \& D) approach with the PPE development model. The model consists of three stages, namely planning, production, and evaluation. Therefore, the researcher will describe the results of the development of Islamic context-based learning materials for students according to the PPE stages.

The first stage is planning. This stage begins with a review of material to be developed in Islamic context-based mathematics learning materials, namely relations, functions, sequences, and series. After the material is determined, the next step is to conduct a literature study to collect references for the materials. After that, the next step is the making of a research instrument lattice that becomes the evaluation criteria for learning materials. The instrument lattice that was made then developed into a research instrument. The research instrument used was a validation sheet and questionnaire. Validation sheets are used to determine eligibility 
based on expert assessment of learning materials, while the questionnaire was used to determine student responses regarding the use of Islamic context-based mathematical learning materials.

The second stage is the production. At this step, the manufacture of Islamic context-based learning material is carried out. The process in this development step includes the development of the contents and components contained in teaching materials consisting of text, pictures, sample questions, and question exercises. The material covered is mathematics material for SMP/MTs, namely relations, functions, sequences, and series. The material is presented using simple and clear language so that it is easily understood by students. Presentation of the text is complemented by images, the use of colors, bold and italics to emphasize material keywords such as the section headings. The font size and font type in this learning material are Bookman Old Style with a font size of $10 \mathrm{pt}$.

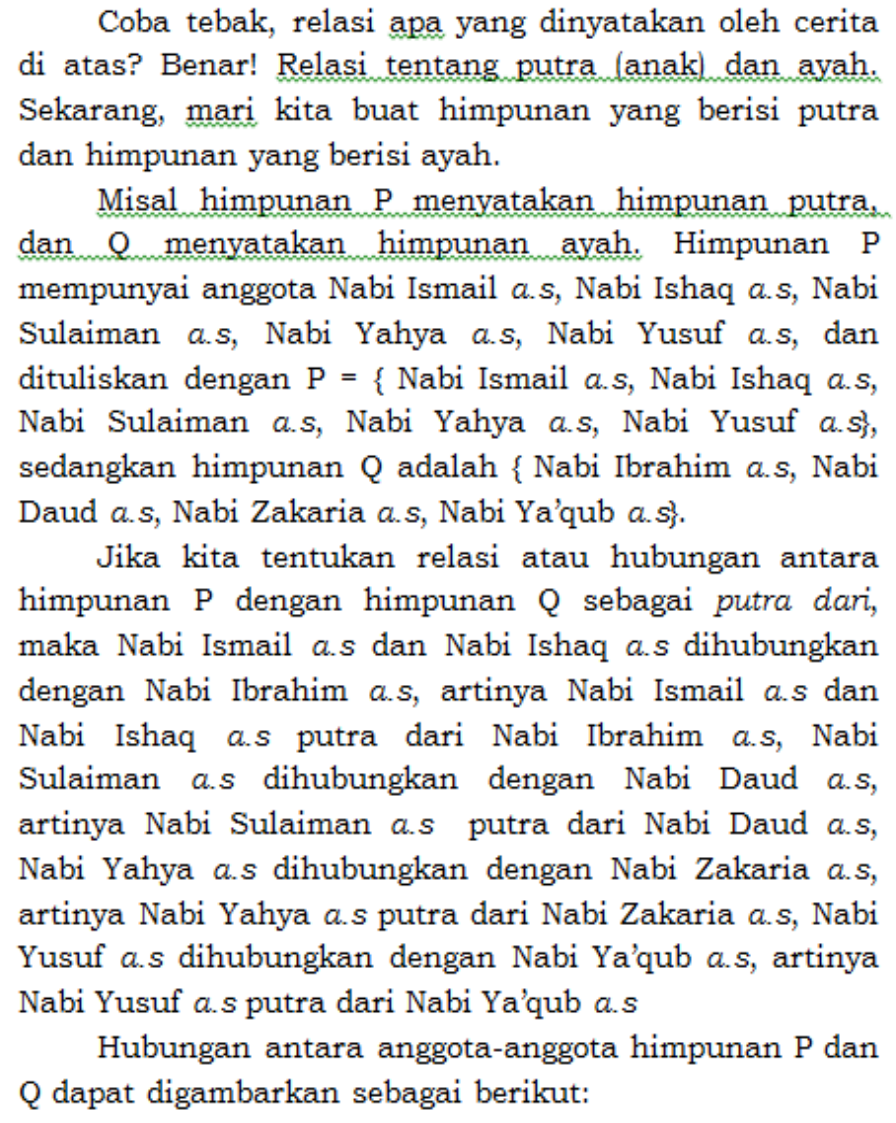

Coba tebak, relasi apa yang dinyatakan oleh cerita di atas? Benar! Relasi tentang putra (anak) dan ayah. Sekarang, mari kita buat himpunan yang berisi putra dan himpunan yang berisi ayah.

Misal himpunan $P$ menyatakan himpunan putra, dan $Q$ menyatakan himpunan ayah. Himpunan $P$ mempunyai anggota Nabi Ismail a.s, Nabi Ishaq a.s, Nabi Sulaiman a.s, Nabi Yahya a.s, Nabi Yusuf a.s, dan dituliskan dengan $P=\{$ Nabi Ismail a.s, Nabi Ishaq a.s, Nabi Sulaiman a.s, Nabi Yahya a.s, Nabi Yusuf a.s\}, sedangkan himpunan $Q$ adalah $\{$ Nabi Ibrahim a.s, Nabi Daud a.s, Nabi Zakaria a.s, Nabi Ya'qub a.s\}.

Jika kita tentukan relasi atau hubungan antara himpunan $\mathrm{P}$ dengan himpunan $\mathrm{Q}$ sebagai putra dari, maka Nabi Ismail a.s dan Nabi Ishaq a.s dihubungkan dengan Nabi Ibrahim a.s, artinya Nabi Ismail a.s dan Nabi Ishaq a.s putra dari Nabi Ibrahim a.s, Nabi Sulaiman a.s dihubungkan dengan Nabi Daud a.s, artinya Nabi Sulaiman a.s putra dari Nabi Daud a.s, Nabi Yahya a.s dihubungkan dengan Nabi Zakaria a.s, artinya Nabi Yahya a.s putra dari Nabi Zakaria a.s, Nabi Yusuf a.s dihubungkan dengan Nabi Ya'qub a.s, artinya Nabi Yusuf a.s putra dari Nabi Ya'qub a.s

Hubungan antara anggota-anggota himpunan P dan $Q$ dapat digambarkan sebagai berikut:

Figure 2. The Display of the Learning Material

The use of color in the image content is consistent and easy to read because the background color used is white. Text and images are presented close together on one page. The presentation of pictures serves to provide an illustration of the material presented.

The third stage is the evaluation. The validation step is carried out so that the feasibility of the developed learning material can be identified based on the assessment of the learning material expert. Learning materials that have been validated are subsequently revised according to expert advice and input during the validation process. The learning material must pass the validation step because, at this step, the learning material will be reviewed by the validators so that the learning material is considered feasible to be used in learning. The following are the results of validation by the expert. 
Table 3. The Results of Expert Validation

\begin{tabular}{cccl}
\hline Aspects assessed & Average & Percentage & \multicolumn{1}{c}{ Criteria } \\
\hline Display & 3.45 & $86.4 \%$ & Feasible of a very good predicate \\
Properness & 3 & $75 \%$ & Feasible of a good predicate \\
\hline
\end{tabular}

Table 3 describes that the data from the validation assessment of experts obtain a percentage of $86.4 \%$ for display and properness gets a percentage of $75 \%$. Even though display and properness aspects are on "feasible" criteria, but it should be revised based on validator suggestions. The validator provides several suggestions for improving the media, as follows: 1) there are some images whose placement does not fit the context of the material. Therefore, the image placement is reorganized into one page with the context. Also, the image is adjusted to the context of the material; 2) Learning material developed has no cover yet. Therefore, an additional cover is provided that presents information such as the title, author and illustration; 3 ) the language used is too long-winded, therefore it is necessary to use a simpler language; 4) there is no picture of Cartesian coordinates to clarify the narrative, therefore it needs to be added.
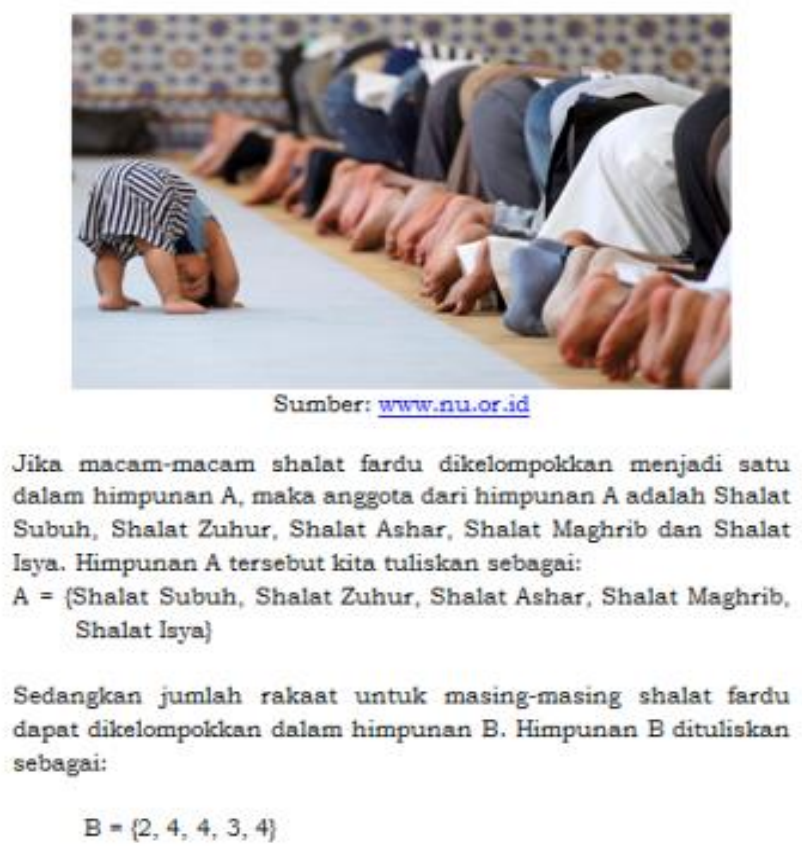

Figure 3. The Display of Learning Material after Revision

Figure 3 describes the examples of learning material display such as picture placement, using colors, font size, and font type after revision. Image content was developed using Geogebra 5.0 software to produce accurate image shapes, as displayed in Figure 4. 


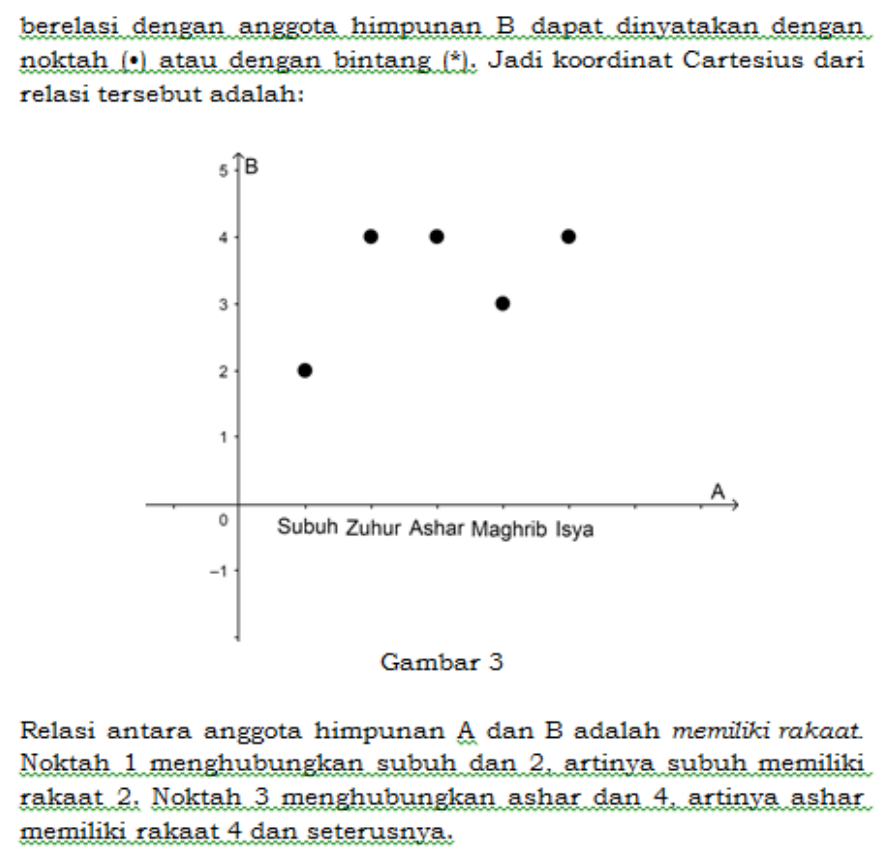

Figure 4. Display Graphic

After the learning material has been revised, the next step is implementation. The implementation step is using the learning material that has been produced in learning. The Islamic context-based mathematics learning material was applied to the first-grade students of Mathematics Education major of IAIN Purwokerto in the subject of junior high school mathematics material study. Before the learning process begins, the researcher provided a pretest to measure students' initial mathematical understanding. In the first meeting, the researchers used the Islamic context-based mathematics learning material to explain the material of relation and function. In the second meeting, the researchers used the Islamic context-based mathematics learning material to explain the material of sequence and series. In the last meeting, the researcher provided a posttest to measure students' final mathematical understanding. Pretest and posttest were given to the students to find out the description of before and after the product implementation. N-gain test is used to find out the students' mathematical understanding improvement after the product implementation. The following are the results of measurements of students' mathematical understanding improvement.

Table 4. Results of Measurement on Students' Mathematical Understanding

\begin{tabular}{lc}
\hline \multicolumn{1}{c}{ Treatment } & Value \\
\hline Average of Pretest & 22.11 \\
Average Posttest & 70.71 \\
Maximum Score & 100 \\
N-Gain & 0.61 \\
\hline
\end{tabular}

Table 4 shows that the average score of students' mathematical understanding before learning using the developed product is 22.11 and after using the developed product, it changes into 70.71. Based on the $\mathrm{N}$-gain results, the increase in students' mathematical understanding is 0.61. If it is included in the criteria for the $\mathrm{N}$-gain factor, the value is moderate. This shows that the increase in students' mathematical understanding of learning after using the developed product is moderate. 
Based on the observations during the learning process, the students pay attention to the learning presented by the teacher because they feel interested in the mathematics material integrated with Islamic studies. Students also pay more attention to learning such as asking questions when the teacher explains the material and being encouraged in the process of learning mathematics in class. Thus, it can be said that students have a fairly high learning interest in learning using Islamic context-based mathematics learning material. This is because learning material designed in the form of this book has at least more value compared to ordinary books that are widely circulated. One of them is following the educational values advocated by the Qur'an, which teaches balance in everything (Yusnita et al, 2016). The use of Islamic context-based mathematics learning materials can stimulate students to be able to connect mathematical topics presented with events, problems encountered in daily life, especially in practicing worship. Therefore, by studying mathematics, students are invited to be critical in facing problems related to other fields of study, as well as problems encountered in daily life.

Facts, concepts, principles, and procedures in this learning material are developed in such a way from students' lives and can be applied in the daily lives of students (Ulpah, 2019). The learning materials explore examples of material from the realities of student life and the material developed can be used by students in daily life practices, so that it is appropriate and meaningful for students' lives. The fact is that many students live in Islamic boarding schools, where Islamic boarding schools teach a lot of Islamic studies. Also, mathematics education curriculum in Islamic college, many courses contain Islamic education, such as Fiqh, History of Islamic culture, Arabic, morality, etc. therefore, the mathematics learning material used should be adapted to the daily context of students who have a lot of Islamic education. Thus, students learn material easier so that their mathematical understanding increases.

\section{CONCLUSIONS}

Based on the results of the study, Islamic context-based mathematics learning material has met the requirements and is considered feasible to be used in the learning process as a supporting media for learning and able to increase students' mathematical understanding through varied learning sources. The use of the Islamic context-based learning material succeeded in increasing students' mathematical understanding by the N-Gain value of 0.61 with a moderate category. It is suggested for further researchers to research Islamic-context based learning material for other mathematics material by developing media or leaning material in improving other mathematics skills.

\section{AUTHOR CONTRIBUTIONS STATEMENT}

MU worked as the main drafter in this study. IN assists the implementation and design of research articles.

\section{REFERENCES}

Agustyarini, Y. \& Jailani, J. (2015). Pengembangan bahan ajar matematika dengan pendekatan kontekstual dan metode penemuan terbimbing untuk meningkatkan EQ dan SQ siswa SMP akselerasi. Jurnal Riset Pendidikan Matematika, 2(1), 135-147.

Alan, U. F. \& Afriansyah, E. A. (2017). Kemampuan pemahaman matematis siswa melalui 
model pembelajaran auditory intellectualy repetition and problem based learning. Jurnal Pendidikan Matematika, 11 (1), 68-78.

Arsanti, M. (2018). Pengembangan bahan ajar mata kuliah penulisan kreatif bermuatan nilainilai pendidikan karakter religius bagi mahasiswa prodi PBSI, FKIP, UNISSULA. Jurnal Kredo, 1(2), 71-90.

Budiman, H., \& Ramdhani, S. (2017). Pengembangan bahan ajar matematika sma berbasis geogebra versi android. Science Tech: Jurnal Ilmu Pengetahuan dan Teknologi, 3(2), 7580 .

Eriana, E., Kartono, K. \& Sugianto, S. (2019). Understanding ability of mathematical concepts and students' self-reliance towards learning by implementing manipulative props (APM) on jigsaw technique. Journal of Primary Education, 8(2), 176-183.

Gazali, G. (2016). Pengembangan bahan ajar matematika untuk siswa SMP berdasarkan teori belajar ausubel. Phytagoras: Jurnal Pendidikan Matematika, 11(2), 182-192.

Hasibuan, A. M., Saragih, S. \& Amry, Z. (2018). Development of learning materials based on realistic mathematics education to improve problem solving ability and student learning independence. International Electronic Journal of Mathematics Education, 14(1), 243252.

Hendriana, H., Rohaeti, E. E. \& Sumarmo, U. (2017). Hards skills dan soft skills matematika siswa. Bandung: PT Refika Aditama

Kariadinata, R., Yaniawati, R., P., Sugilar, H. \& Riyandani, D. (2019). Learning motivation and mathematical understanding of students of islamic junior high school through active knowledge learning strategy. Infinity Journal of Mathematics Education, 8(1), 31-42.

Kharisma, J. Y. \& Asman, A. (2018). Pengembangan bahan ajar matematika berbasis masalah berorientasi pada kemampuan pemecahan masalah matematis dan prestasi belajar matematika. Indonesian Journal of Mathematics Education, 1(1), 34-46.

Lestari, I. (2018). Pengembangan bahan ajar matematika dengan memanfaatkan geogebra untuk meningkatkan pemahaman konsep. GAUSS: Jurnal Pendidikan Matematika, 1(1), 26-37.

Maharani, A. (2017). Pengembangan bahan ajar matematika berbasis macromedia flash materi operasi bilangan real SMK teknologi dan rekayasa. Jurnal Teori dan Riset Matematika (TEOREMA), 2(1), 1-10.

Mahmudi, T., Iksan, M. \& Johar, R. (2018). The improvement of students mathematical understanding and self-concept through a discovery learning model. Proceedings of AICS-Social Sciences, 149-153.

Mardiana, S., Susiswo, S. \& Hidayanto, E. (2017). Students' growth of mathematical understanding in solving derivative problem. IOSR Journal of Research and Method in Education, 7(3), 36-41.

Minarni, A., Napitupulu, E. E. \& Husein, R. (2016). Mathematical understanding and representation ability of public junior high school in north Sumatra. Journal on Mathematics Education, 7 (1), 43-56.

Nurhasanah, A. (2017). Pengembangan bahan ajar pendidikan matematika I untuk 
meningkatkan kualitas pembelajaran mahasiswa PGSD universitas Kuningan. Jurnal Pendidikan Dasar Eduhumaniora, 9 (2), 67-74.

Nurhidayati, S., Tayeb, T. \& Baharuddin, (2017). Pengembangan bahan ajar matematika berbasis masalah untuk memfasilitasi pencapaian kemampuan penalaran pada pokok bahasan perbandingan kelas VII MTsN model Makasar. MaPan: Jurnal Matematika dan Pembelajaran, 5(2), 236-250.

Peranginangin, S., A., Saragih, S. \& Siagian P. (2019). Development of learning materials through pbl with karo culture context to improve students' problem solving ability and self-efficacy. International Electronic Journal of Mathematics Education, 14(2), 265274.

Purwadi, I, M. A., Sudiarta, I. G. P., \& Suparta, I. N. (2019). The effect of concrete-pictorialabstract strategy toward students' mathematical conceptual understanding and mathematical representation on fractions. International Journal of Instruction, 12(1), 1113-1126.

Putri, F. M.. (2016). Pengembangan bahan ajar matematika dasar layanan jurusan non eksak. Jurnal Pendidikan Matematika dan Matematika Fibonacci, 2(1), 44-52.

Safitri, S. (2017). Pengembangan bahan ajar matematika level IGCSE berbasis tugas terstruktur bagi mahasiswa calon guru matematika. Jurnal Penelitian dan Pembelajaran Matematika, 9(1), 102-108.

Santrock, J. W. (2012). Life-span development (Perkembangan Masa Hidup Edisi 13 Jilid 1, Penerjemah: Widyasinta). Jakarta: Erlangga.

Saputra, R., Falahudin, I. \& Testiana, G. (2016). Pengembangan bahan ajar matematika berbasis komputer untuk siswa kelas VIII di SMP negeri 19 Palembang. Jurnal Pendidikan Matematika JPM RAFA, 2(2), 249-268.

Somakim, S., Suharman, A., Madang, K. \& Taufiq. (2016). Developing teaching materials PISA-based for mathematics and science of junior high school. Journal of Education and Practice, 7(13), 73-77.

Sugiyono, S. (2019). Metode penelitian \& pengembangan (research and development). Bandung: Alfabeta

Ulandari, L., Amry, Z. \& Saragih, S. (2019). Development of learning materials based on realistic mathematics education approach to improve students' mathematical problem solving ability and self-efficacy. International Electronic Journal of Mathematics Education, 14(2), 375-383.

Ulpah, M. (2017). Analisis hasil pembelajaran matematika pada ranah afektif mahasiswa calon guru di IAIN Purwokerto. Jurnal Insania, 22(2), 354-365.

Ulpah, M. (2019). Self-efficacy dalam pembelajaran matematika siswa madrasah aliyah. Jurnal Insania, 24(1), 167-176.

Wulandari, W. (2017). Kelayakan aspek materi dan media dalam pengembangan buku ajar sastra lama. Jurnal Gramatika, 3(2), 162-172.

Yusnita, R., Masykur, S. \& Suherman. (2016). Modifikasi model pembelajaran gerlach dan ely 
Ulpah, M. \& Novikasari, I.

melalui integrasi nilai-nilai keislaman sebagai upaya meningkatkan kemampuan representasi matematis. Aljabar: Jurnal Pembelajaran Matematika, 7 (1), 29-38.

Zulkifli, Z. \& Royes, N. (2018). Profesionalisme guru dalam mengembangkan materi ajar bahasa arab di MIN 1 Palembang. JIP: Jurnal Ilmiah PGMI, 3(2), 120-133. 